\title{
USING TOTAL WATER FOOTPRINT OF NATIONAL CONSUMPTION AS SUSTAINABLE DEVELOPMENT INDICATOR - A CRITICAL REVIEW
}

Jean Vasile Andrei ${ }^{1}$, Aurelia Patrascu ${ }^{2}$, Mihaela Cristina Drăgoi ${ }^{3}$, Rodica-Manuela Gogonea ${ }^{4}$, Radu Serban Zaharia ${ }^{5}$

*Corresponding author E-mail: rzaharia992@gmail.com

A R T I C L E I N F O
Original Article
Received: 13 September 2018
Accepted: 17 November 2018
doi:10.5937/ekoPolj1804427A
UDC 351.778.3:502.131.1(4-672EU)

Keywords:

water footprint, EU28, sustainable development, Normalized Entropy, ecologic footprint, territorial distribution

JEL: F64, O44, Q5

\section{A B S T R A C T}

In highly competitive and modern economies, water represents a determinant productive resource and using the water footprint (WF) as a possible indicator in assessing sustainable development is integrated in the overall framework of macroeconomic efficiency analysis. The main aim of this paper is to argue that water footprint could represent a proper indicator in analyzing the sustainable economic development. In this context the territorial distribution of water footprint across the $28 \mathrm{EU}$ countries is analyzed in order to substantiate decisions and achieve sustainable economic development forecasts and strategies at European level. The results have led to the conclusion that, overall, the total water footprint of national consumption in the $28 \mathrm{EU}$ Member States has a very low degree of concentration, therefore, tends towards uniformity. With regard to the three types of water footprint, the main characteristic outcome of the research is the low degree of concentration for gray and green water footprint, while blue water footprint proves a moderate degree of concentration.

(C) 2018 EA. All rights reserved.

1 Ph.D. Jean Vasile Andrei, associate professor, Faculty of Economic Sciences, Petroleum -Gas University of Ploiesti, B-dul. Bucuresti, No.39, 100680, Ploiesti, Prahova, Romania, andrei_ jeanvasile@yahoo.com, ORCID ID /orcid.org/0000-0002-8332-6537

2 Ph.D. Aurelia Patrascu, associate professor, Faculty of Economic Sciences, Petroleum -Gas University of Ploiesti, B-dul Bucuresti, No.39, 100680, Ploiesti, Prahova, Romania, patrascuaura@yahoo.com

3 Ph.D. Mihaela Cristina Drăgoi, associate professor, Bucharest University of Economic Studies, Faculty of International Business and Economics, Caderea Bastiliei no.2-10, 010615 Bucharest, Romania, cristina.dragoi@rei.ase.ro, ORCID ID https://orcid.org/0000-0002-8071-0832

4 Ph.D. Rodica-Manuela Gogonea, associate professor, Bucharest University of Economic Studies, 15-17 Dorobanti St., Sector 1, Bucharest 010552, Romania, manuela.gogonea@gmail.com

5 Ph.D student, Radu Serban Zaharia, Faculty of Economics, Doctoral School, University "Valahia" of Targoviste, Str. Aleea Sinaia, No. 13, Targoviste, 130004 Dambovita, Romania, rzaharia992@gmail.com

http://ea.bg.ac.rs 


\section{Introduction}

The human being, as a beneficiary of the environment, provokes and generates malfunctions which in time have had a significant impact on the economic and human development. Meeting the growing needs of large human communities, consuming environmental services and territorial resources, have led to less favorable environmental effects. Water represents an essential component of the environment, with a complex use (Galli et al., 2012; Gallopin and Rijsberman, 2000; Hoekstra and Mekonnen, 2012). Monitoring the quality and quantity of water is very important in preventing several problems related to the deficit or the loss manifested in various sectors of the economic activity (Kaplowitz and Witter, 2008).

Moreover, water denotes a limited economic resource that directly and irremediably affects the level of competitiveness of the European economy. The intensity of climate change, and especially the frequency of occurrence and manifestation of phenomena such as drought, but also the growing needs of the population, calls for a complex approach to water issues. Water availability and access to sources of supply are major challenges for EU Member States, given the growing share of economic sectors with a high degree of water dependency. The growing need for securing water resources also requires the optimization of consumption and of the geographical distribution of these resources across the EU.

Integrated and efficient water resource management involves a complex process of measures that include, besides water savings, the reuse of waste water, water transfers and desalination. Extending the life cycle of water must in this context be a fundamental objective for achieving sustainable economic development, not only from a sectoral perspective but also as an integrated management tool. At the same time, the transformations of the paradigm of the European economy imposed the necessity of identifying and promoting alternative and reliable sources for ensuring a sustainable water supply in full compliance with the objectives of encouraging the circular economy at European level. Thus, the following figures present sources of drinking water in the European Union (Figure 1) and in its Member States (Figure 2) for the period ranging from 2011 to 2013, according to the European Commission (2016).

Figure 1: Sources of drinking water in the EU (2011 to 2013)

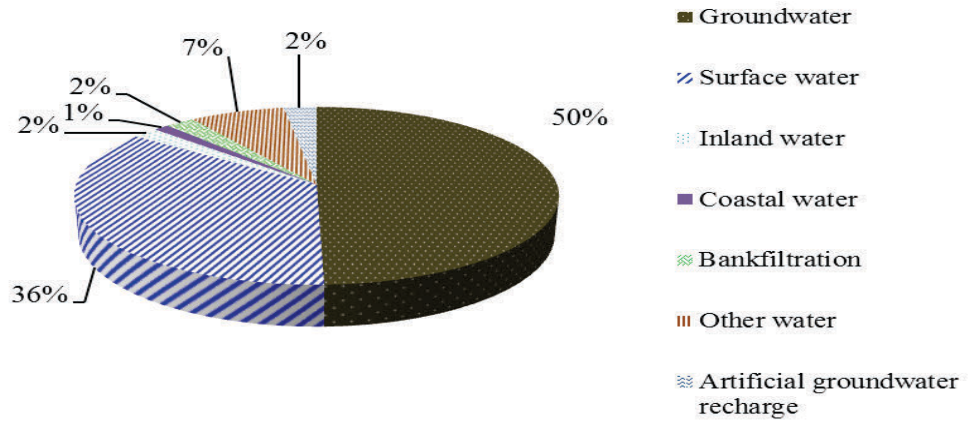

Source: European Commission (2016) 
Figure 1 shows that drinking water at EU level is ensured from a wide range of supply sources in which groundwater provides about half of the required amount, while surface water cover only $36 \%$ of the necessary drinking water.

This distribution of supply sources requires the promotion and application of a dynamic water management, from the perspective of security of supply and diversity of sources. However, if we consider the distribution of sources for drinking water in the Member States for the same period (Figure 2), one can notice a non-uniform spread of drinking water sources. Thus, some countries such as Austria and Germany secure their needs from the exploitation of underground water resources, while countries such as Romania and Bulgaria through a mix of exploitation composed both from surface and underground sources.

Figure 2: Sources of drinking water in EU Member States (2011 to 2013)

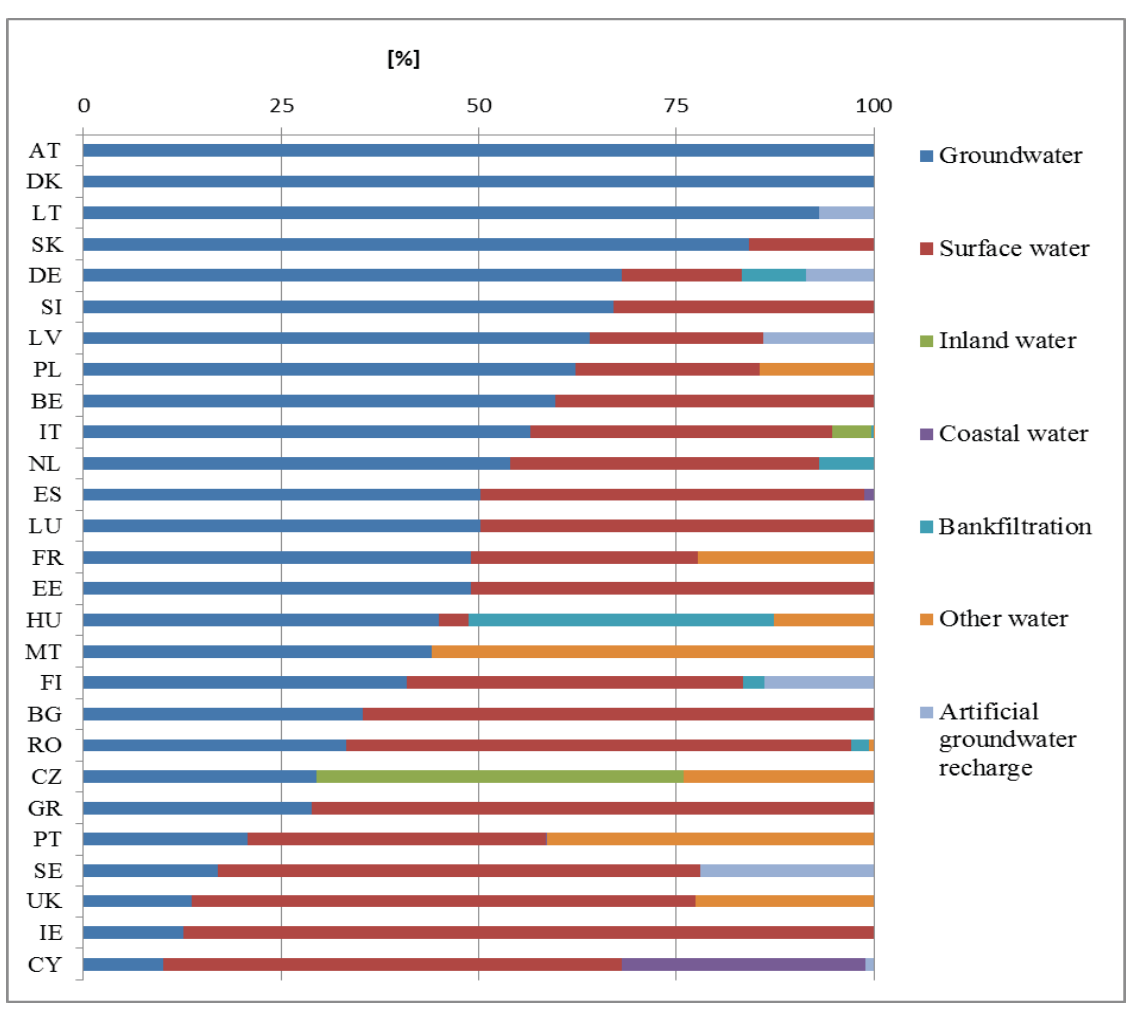

Source: European Commission (2016)

The evolution of water importance and usage in economy has transformed this resource in a potential indicator for understanding sustainable development. In this context, the need for developing a representative indicator has imposed water as a significant candidate in achieveing this goal. Also, given the great importance of water resources in the economy and the multiple roles they play in the everyday life of both people and companies, understanding and promoting an indicator such as water footprint as an 
instrument in sustainable development analysis is more than opportune. Thus, various researches regarding national water footprint can be identified for several EU Member States, among which the study of Varela-Ortega et al. (2009) analyzing this indicator in Spain, of Sonnenberg, Chapagain, Geiger, and August (2009) for Germany, van Oel, Mekonnen, and Hoekstra (2009) in the case of Netherlands and Sima and Gheorghe (2015) in the case of Romania.

Water footprint represents the indicator that highlights the quantity of water consumed by people in order to produce goods and services, under the impact of direct factors of consumption such as: climatic conditions, agricultural practice, consumption volume of Gross National Income and the consumption model specific to each country (Hoekstra and Chapagain, 2007). As emphasized by available literature (Vanham and Bidoglio, 2013), despite the fact that the water footprint is presented as one aggregate number, it represents a multidimensional indicator of water usage, by combining different types of water consumption and highlighting pollution as a function of space and time.

Furthermore, the water footprint has been analyzed as possible sustainable development indicator in several studies (Lamastra, Suciu, Novelli, and Trevisan, 2014; Varela-Ortega et al., 2009) which may represent important steps in understanding the role and influence of this indicator in shaping the environmental economic behavior.

In adjacent connection with the phenomenon of sustainable development at global level, world organizations have put forward the quantification of the water footprint. The concept of water footprint, closely linked to virtual water is used in analogy with the ecological footprint (Ridoutt and Pfister, 2013; Zhao, Chen, and Yang, 2009).

In this context, the purpose of this research is to analyze the territorial distribution of water footprint across the $28 \mathrm{EU}$ countries in order to substantiate decisions and achieve sustainable economic development forecasts and strategies at European level (Vanham and Bidoglio, 2013). The analysis of territorial distribution was conducted both by measuring the degree of territorial concentration of the water footprint on the 28 EU countries, by graphical and numerical methods, and also by cluster grouping. At the same time, the study was developed taking into consideration the three fundamental components of water footprint: green, blue and gray water footprint of national consumption per capita for the $28 \mathrm{EU}$ countries.

The EU countries are targeting water consumption both in relation to national requirements and to certain consumption related to outsourcing process. Thus, there are countries which, involved in the outsourcing process, considered that the products they import are in direct interdependence with the process of water exhaustion or pollution for the countries that produce them.

The current study is structured into five sections as follows: a brief introduction on the importance of the analysis of territorial distribution of water footprint across the 28 EU countries; the second section includes the methodology and datasets used for research; the third section contains the results of the analysis of the territorial footprint 
distribution in the 28 European Union's Member States as a result of the concentration indicators, the construction of the concentration curves and the grouping of the EU member states into clusters. The final section is summarizing the results of the analysis with proposals and visions for future research.

\section{Research methodology}

The basis of the study consisted of the series of statistical data on water footprint of national consumption per capita, ( $\left.\mathrm{m}^{3} / \mathrm{yr} / \mathrm{cap}\right)$ available in Mekonnen and Hoekstra (2011a, 2011b), synthesized from the time range 1996-2005 and structured as:

$$
X=\left\{X_{i, j}\right\}_{i=1, n, j=1, m}
$$

In (1), $n=28$ represents the EU-28 Member States, and $m=4$ stands for the three types of water under analysis (green, blue and gray) and total water.

Taking into account the method of calculating the water footprint, the study envisaged the application of methods by which to examine and measure the distribution of the water footprint of national consumption per capita. Thus, the assessment of the concentration of water footprint of the national consumption per capita $\left(\mathrm{m}^{3} / \mathrm{yr} / \mathrm{cap}\right)$ shown by major consumption category and by internal and external component in the EU countries is highlighted by applying both graphical procedures (concentration curve) and numerical procedures (Kaplowitz and Witter (2008) Zaiontz (2017) and (Wessa, 2018)

The graphical procedure used in the analysis of territorial concentration of the water footprint of national consumption per capita shown by major consumption category and by internal and external component is represented by the concentration curve. Depending on the method of determining the Gini Coefficient, as an expression of the level of concentration, the concentration curve of the water footprint of national consumption per capita was completed in two variants. The first variant reflects 6 variation ranges in which the EU countries have grouped, as a result of applying the trapezoid method, and the second is in relation to all EU countries (Lorenz curve).

The degree of concentration is represented by the deviation of the concentration curve (Figure 3) from the diagonal of the square, specifically by the size of the concentration surface. The larger the concentration area, hence the disparity between countries in terms of the water footprint of national consumption per capita is more accentuated, more pronounced the concentration is. 
Figure 3: The theoretical curve of concentration of water footprint by country

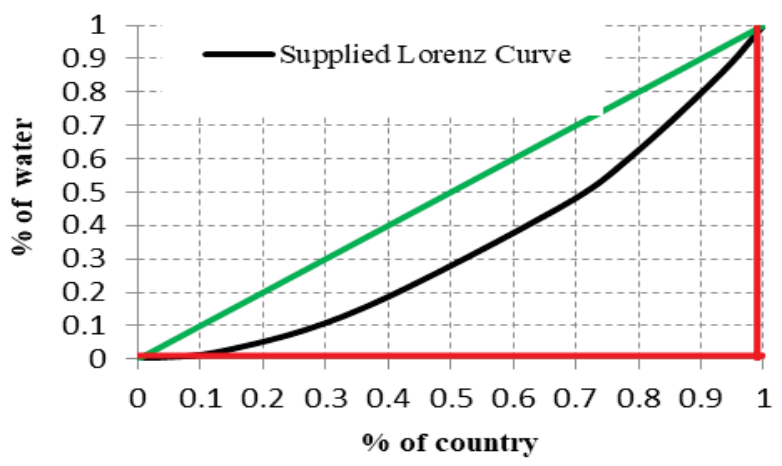

Source: authors`own computation based on Mekonnen and Hoekstra (2011a, 2011b)

The main numerical indicator used for water footprint analysis of national consumption per capita is Gini Coefficient (Săvoiu, Crăciuneanu, \& Țaicu, 2010) given by (2):

$$
\boldsymbol{G}=\sqrt{\sum_{i=1}^{n} g_{i}^{2}}, \quad g_{i}=\frac{x_{i}}{\sum_{i=1}^{n} x_{i}}, \quad G \in\left[\sqrt{\frac{1}{n}}, 1\right]
$$

In (2) xi designates water footprint analysis of national consumption per capita at country level and gi represents the water footprint of national consumption per capita corresponding to that country. In this case $n=8, i=\overline{1,8}$.

Additionally, for analyzing the level of concentration, the following indicators were used: Entropy, Maximum Entropy, Normalized Entropy, Herfindahl, Normalized Herfindahl, Gini Coefficient, and Concentration Coefficient.

To highlight the groups of Member States in which the concentration phenomenon identified by the application of the presented methods appears, the Hierarchical Cluster methodology was used, starting from the data series (1) to which the following transformation was applied (Mooi and Sarstedt, 2011):

$$
Y=\left\{y_{i j}\right\}_{i=\overline{1, n}, j=\overline{1, m}}, y_{j}=\frac{x_{j}-\bar{x}_{j}}{\sigma_{j}}, i=\overline{1,8}, j=\overline{1,4}
$$

Subsequently, in order to generate the Proximity Matrix, the Euclidian distance was used, while for determining the distance between clusters the Average Linkage method was employed.

For testing the statistical significance of the mean values of the variables used for generating the clusters, the Welch's Test and F test were employed (Keselman, Othman, Wilcox, and Fradette, 2004). 
The results indicate the location of each country at European level and the role it has in relation to the other countries regarding the changes over time concerning the water footprint of national consumption per capita. This aspect envisages the development and implementation of policies and strategies aimed at sustainable economic development for the European area.

\section{Results and discussion}

Since the water footprint refers to the amount needed to support the population of EU countries, the study started with the identification of the level of concentration of the total water footprint of national consumption per capita for the EU28 countries.

At aggregate level, the direct factors of consumption that determine the water footprint of national consumption per capita (volume of consumption related to Gross National Income, consumption pattern, climatic conditions, agricultural practice) have fluctuated through compensation, hence the 28 countries, as a whole, present a fairly low concentration.

The reduced concentration of $12.68 \%$ of the total water footprint of national consumption per capita determined at the cumulative level of EU countries is evidenced both by the calculation of the concentration indicators (Table 1) and by the graphic representation as a result of the application of the trapezoid method.

The Entropy indicator with a value of 3.307, close to the value of Maximum Entropy of 3.33 and Normalized Entropy with a high value of 0.9925 pointing to the upper limit 1 , indicates a low concentration of total water footprint of national consumption per EU country. This statement is also confirmed by the results of the indicators Herfindahl (0.0375) and Normalized Herfindahl (0.0019), since they tend towards 0.0357 , respectively 0 .

Table 1: Concentration indicators for total water footprint of national consumption per capita

\begin{tabular}{|l|c|}
\hline \multicolumn{1}{|c|}{ Concentration indicators } & Degree of concentration \\
\hline Entropy & 3.3073 \\
\hline Maximum Entropy & 3.3322 \\
\hline Normalized Entropy & 0.9925 \\
\hline Herfindahl & 0.0375 \\
\hline Normalized Herfindahl & 0.0019 \\
\hline Gini Coefficient & 0.1268 \\
\hline Concentration Coefficient & 0.1315 \\
\hline
\end{tabular}

Source: authors`own computations based on Mekonnen and Hoekstra (2011a, 2011b)

The concentration curve of EU countries, distributed into groups by total water footprint of national consumption per capita (Figure 4), is rather close to the diagonal of the square, confirming the low concentration of EU countries regarding the water footprint of national consumption per capita. 
Figure 4: Concentration curve for total water footprint of national consumption per capita

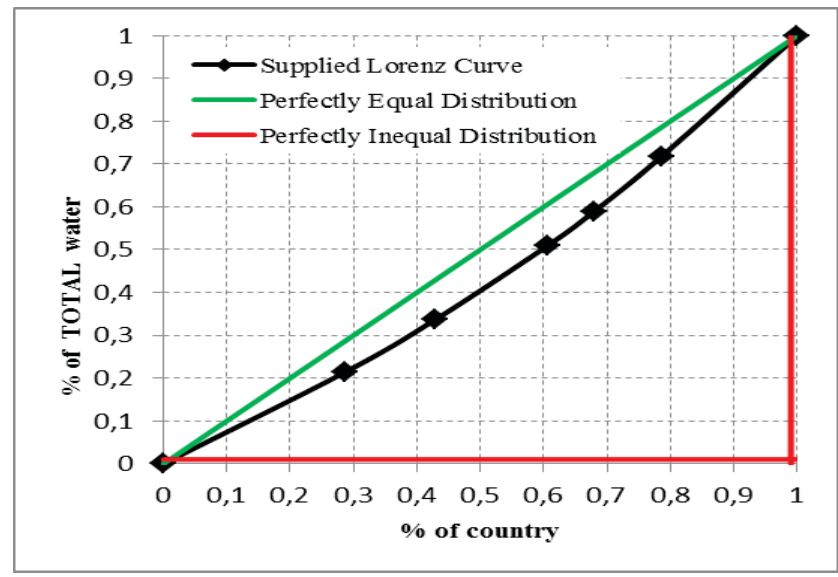

Source: authors`own computations based on Mekonnen and Hoekstra (2011a, 2011b)

In the Gini form, applying the trapezoid method led to the division of EU countries into 6 groups regarding water footprint of national consumption per capita (Figure 5).

Figure 5: Distribution of EU countries by groups of total water footprint of national consumption per capita

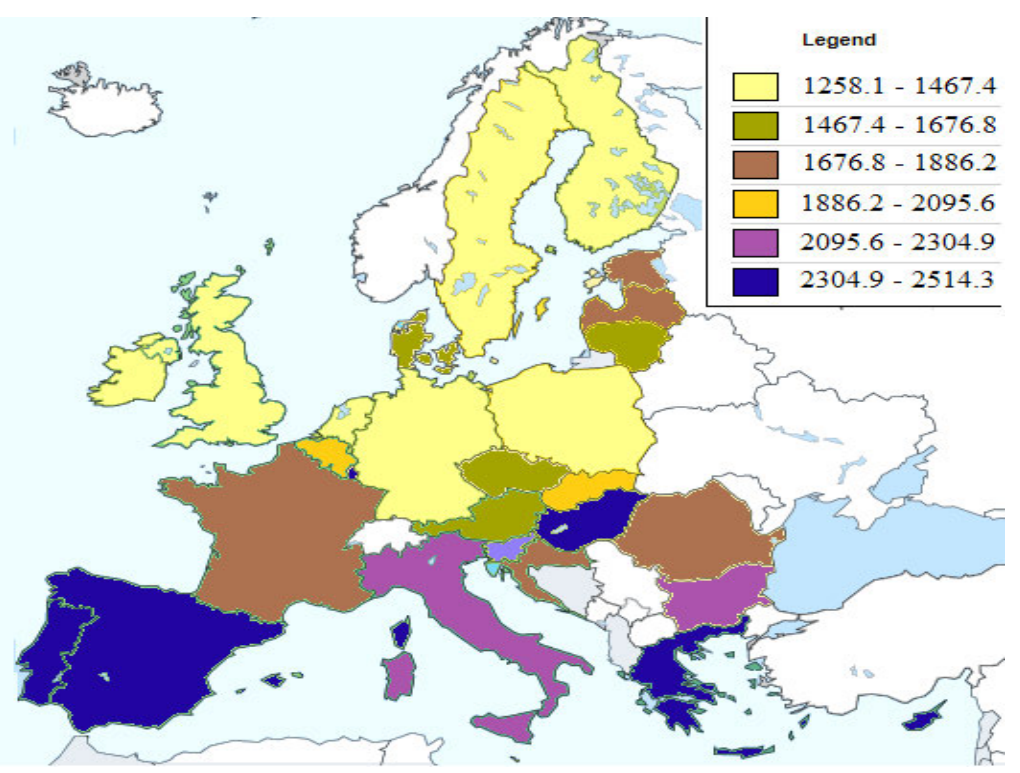

Source: authors`own design on Mekonnen and Hoekstra (2011a, 2011b) 
In national governmental plans, EU countries have been targeting water consumption to be set both in relation to national requirements and in relation to that consumption leveling the outsourcing process. Water dependence and the results of the algorithm for calculating the trapezoids have led to the conclusion that the UK, Ireland, Slovakia, Poland, Finland, Germany, Sweden, and the Netherlands have the lowest consumption (between 1,258.1 and 1,467.43 $\mathrm{m}^{3} / \mathrm{yr} / \mathrm{cap}$ ) as it was shown in Mekonnen and Hoekstra (2011a, 2011b). They account for $23.32 \%$ of all countries that account for $28.57 \%$ of the total water footprint of national consumption per capita.

If we also include Lithuania, Austria, Denmark and the Czech Republic, members of the second group with a slightly higher consumption, then $33.62 \%$ of all countries will account for $42.86 \%$ of the total water footprint of national consumption per capita. With more water consumed than previous groups, another 5 countries (Croatia, Romania, Estonia, France and Latvia) are added to the 12 countries previously mentioned, so that more than half of all countries $(51.03 \%)$ make up $60.71 \%$ of the total water footprint of national consumption per capita. At the level of the fourth group, the 17 countries together with Belgium and Slovenia will represent $58.82 \%$ of their total, accounting for $67.86 \%$ of the total water footprint of national consumption per capita.

The fifth group indicates a distribution of $78.57 \%$ of the total water footprint of national consumption per capita which belongs to $71.78 \%$ of the total EU countries (Malta, Bulgaria and Italy were added to the 19 countries). The countries of the last group, Greece, Hungary, Cyprus, Spain, Portugal and Luxembourg are the largest consumers of water (consumption between 2,304.93-2,514.30 $\mathrm{m}^{3} / \mathrm{yr} / \mathrm{cap}$ ), as main consumers of agricultural products, especially of meat. This complements the distribution of the water footprint of national consumption per capita across all European Union's countries.

For a clearer picture of the place occupied by each country in distributing the water footprint of national consumption per capita at European level, completing the study with a more detailed analysis of the territorial distribution of the three types of watergreen, blue and gray - proved extremely useful.

Table 2: Concentration indicators for total water footprint of national consumption per capita for the three types of water

\begin{tabular}{|l|c|c|c|c|c|c|}
\hline \multirow{2}{*}{$\begin{array}{c}\text { Concentration } \\
\text { indicators }\end{array}$} & \multicolumn{2}{|c|}{ Entropy } & \multicolumn{2}{c|}{ Herfindahl } & \multicolumn{2}{c|}{ Gini } \\
\cline { 2 - 7 } & Indicator & $\begin{array}{c}\text { Normalized } \\
\text { Entropy }\end{array}$ & Indicator & $\begin{array}{c}\text { Normalized } \\
\text { Herfindahl }\end{array}$ & $\begin{array}{c}\text { Gini } \\
\text { Coefficient }\end{array}$ & $\begin{array}{c}\text { Concentration } \\
\text { Coefficient }\end{array}$ \\
\hline Green_Total & 3.306 & 0.992 & 0.037 & 0.002 & 0.131 & 0.136 \\
\hline Blue_Total & 3.134 & 0.940 & 0.053 & 0.018 & 0.340 & 0.353 \\
\hline Gray_Total & 3.303 & 0.991 & 0.038 & 0.002 & 0.135 & 0.139 \\
\hline
\end{tabular}

Source: authors`own computation based on Mekonnen and Hoekstra (2011a, 2011b)

In terms of total green water footprint of national consumption per capita for EU countries, determining the degree of territorial concentration of countries presents a particular feature. Regarding the amount of rainwater consumed, with a direct impact 
on agricultural products, the data recorded for each country led to a concentration of the lower values of the total green water footprint of national consumption per capita, ranging from 915.5 to $1,428.36 \mathrm{~m}^{3} / \mathrm{yr} /$ cap in 19 European countries. (Mekonnen and Hoekstra (2011a, 2011b)

Also, as it can be remarked from (Mekonnen and Hoekstra (2011a, 2011b), after a significant gap of $297 \mathrm{~m}^{3} / \mathrm{yr} / \mathrm{cap}$, a noteworthy total water footprint of national consumption per capita will be recorded in only 9 countries: Greece, Malta, Cyprus, Italy (1,599.30-1,770.24 m³/yr/cap), Spain, Bulgaria, Portugal, Hungary, Luxembourg (1,770.24-1,941.17 $\left.\mathrm{m}^{3} / \mathrm{yr} / \mathrm{cap}\right)$ Mekonnen and Hoekstra (2011a, 2011b). These nine countries, differing from one country to another, have climate and landscapes that are not very favorable, show a high consumption of agricultural products (especially meat, a large agricultural consumer of water), and have farming practices that do not offer the possibility of important water savings.

Figure 6: Distribution of EU countries by groups according to the total green water footprint of national consumption per capita

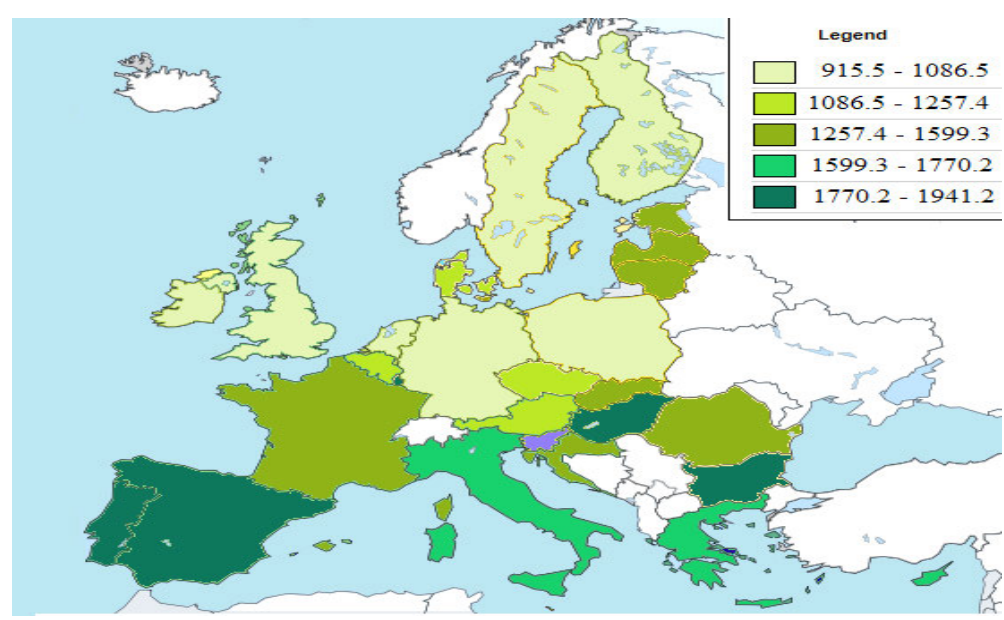

Source: authors`own design based on Mekonnen and Hoekstra (2011a, 2011b)

However, across all EU countries, as shown in Figure 6, the particularity of the high level of the total green water footprint of national consumption per capita of the 9 countries did not greatly affect the degree of territorial concentration. The high value of the Entropy indicator, close to Maximum Entropy, and the one of Normalized Entropy, which tends to the upper limit of value 1 (Table 2), show low concentration of the EU countries regarding total green water footprint of national consumption per capita. This concentration tendency is also confirmed by the values of the other concentration

indicators that point towards $\frac{1}{n}=0.0357$ or towards 0 . 
The Lorenz concentration curve of EU countries by total green water footprint of national consumption per capita (Figure 7(a)) also indicates a fairly uniform territorial distribution of the countries, being very close to the diagonal of the square.

Figure 7: Concentration curve for total water footprint of national consumption per capita for the three major categories

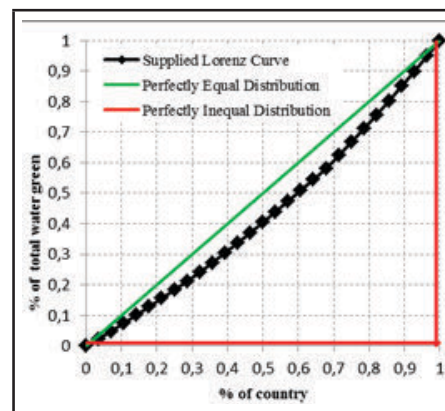

(a) Green_Total

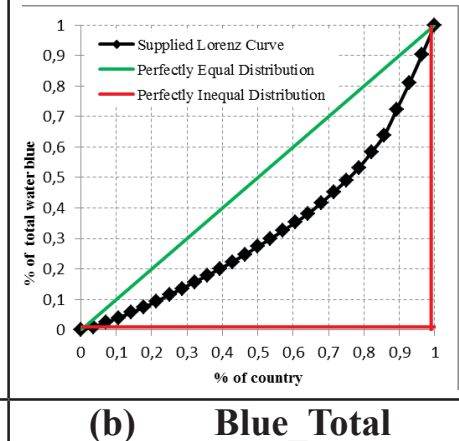

(b)

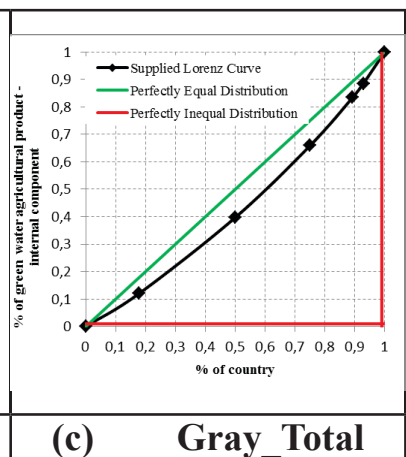

Source: authors`own computations based on Mekonnen and Hoekstra (2011a, 2011b)

The particularity of a significant gap is also encountered when analyzing the concentration of countries for the total blue water footprint of national consumption per capita.

Figure 8: Distribution of EU countries by groups according to the total blue water footprint of national consumption per capita

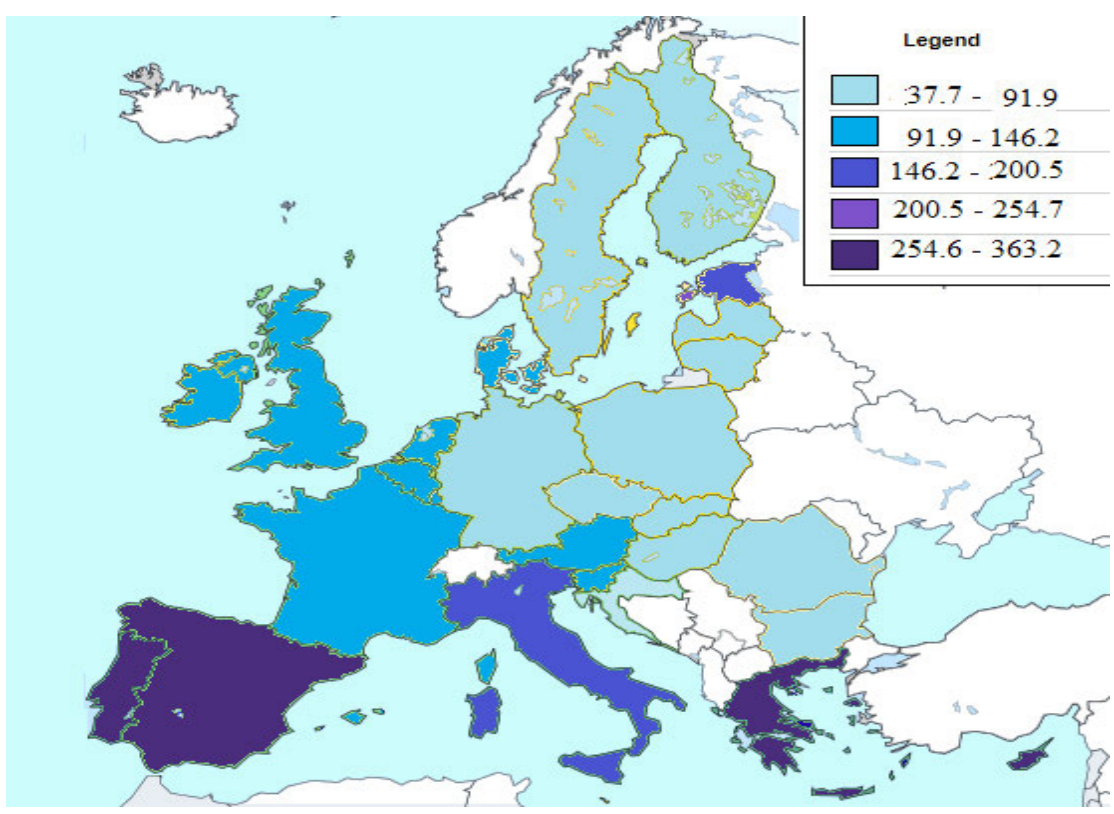

Source: authors`own design based on Mekonnen and Hoekstra (2011a, 2011b) 
A remark deriving from Figure 8 emphasizes that Spain, Greece, Cyprus and Portugal are four countries with blue water footprint of national consumption per capita with very high values ranging from 321.2 to $363.2 \mathrm{~m}^{3} / \mathrm{yr} / \mathrm{cap}$ compared to the other 24 countries, being, as already mentioned, large consumers of agricultural products. The gap between the two groups (the group with the 4 countries and the remaining 24 countries) is significant as it was reviled in (Mekonnen and Hoekstra 2011a, 2011b) $114.5 \mathrm{~m}^{3} / \mathrm{yr} / \mathrm{cap}$, given that between the minimum of $37.7 \mathrm{~m}^{3} / \mathrm{yr} / \mathrm{cap}$ (Croatia) and the maximum of $206.7 \mathrm{~m}^{3} / \mathrm{yr} / \mathrm{cap}$ (Malta) 24 countries are distributed.

The territorial concentration degree of $34 \%$ of the total blue water footprint of national consumption per capita by country at EU level is quite low, but higher than in the case of the total green water footprint of national consumption per capita, which requires special attention to the issues deriving from blue water footprint of national consumption per capita. This is evidenced by the values of the concentration indicators determined in Table 2 that are higher than the ones of total green water footprint of national consumption per capita, although they tend towards the upper limits for Entropy and Normalized Entropy and towards the lower limits for Herfindahl, Normalized Herfindahl, and Gini Coefficient.

At the same time, the graphical representation (Figure 7(b)), with the traced curve built at a higher distance than the diagonal, reveals a more marked disparity among countries concerning the total blue water footprint of national consumption per capita compared to the total green water footprint of national consumption per capita.

Started form the consideration that water footprint is a major component of the environmental footprint, the gray water footprint (Figure 9) component represents a proper indictor in highlighting the human pressure on the environment. In this context analyzing the gray water footprint as a component in total water footprint of national consumption per capita could be considered justified in revealing the sustainable development. Starting from the main assumption that gray water footprint has the lowest degree of concentration among the analyzed countries; it could be considered as a basic indicator in understanding the economic impact on the environment pressure. Moreover, the analysis shows that the gray water footprint distribution is very close to the uniform one.

Belgium and Slovenia are the countries with the highest total gray water footprint of national consumption per capita as it was measured in (Mekonnen and Hoekstra (2011a, 2011b) ranging from 507.05 to $569.50 \mathrm{~m}^{3} / \mathrm{yr} / \mathrm{cap}$, followed by Luxembourg with $469.6 \mathrm{~m}^{3} / \mathrm{yr} / \mathrm{cap}$. The succeeding group includes Italy, Hungary, Bulgaria, and Latvia with total gray water footprint of national consumption per capita between 382.16 and $444.61 \mathrm{~m}^{3} / \mathrm{yr} / \mathrm{cap}$. The Czech Republic, Malta, Poland, Spain, Cyprus, Greece, and Austria are 7 countries with values between 319.72 and $382.16 \mathrm{~m}^{3} / \mathrm{yr} / \mathrm{cap}$. Most countries (Romania, Finland, Netherlands, Germany, Portugal, Croatia, France, Sweden, and Denmark) have a total gray water footprint ranging from 257.27 to 319.72 $\mathrm{m}^{3} / \mathrm{yr} / \mathrm{cap}$. The last analyzed group includes the countries with the lowest total gray 
water footprint of national consumption per capita extending from 194.83 to $257.27 \mathrm{~m}^{3} /$ yr/cap. (Mekonnen and Hoekstra (2011a, 2011b)

Figure 9: Distribution of EU countries by groups according to the total gray water footprint of national consumption per capita

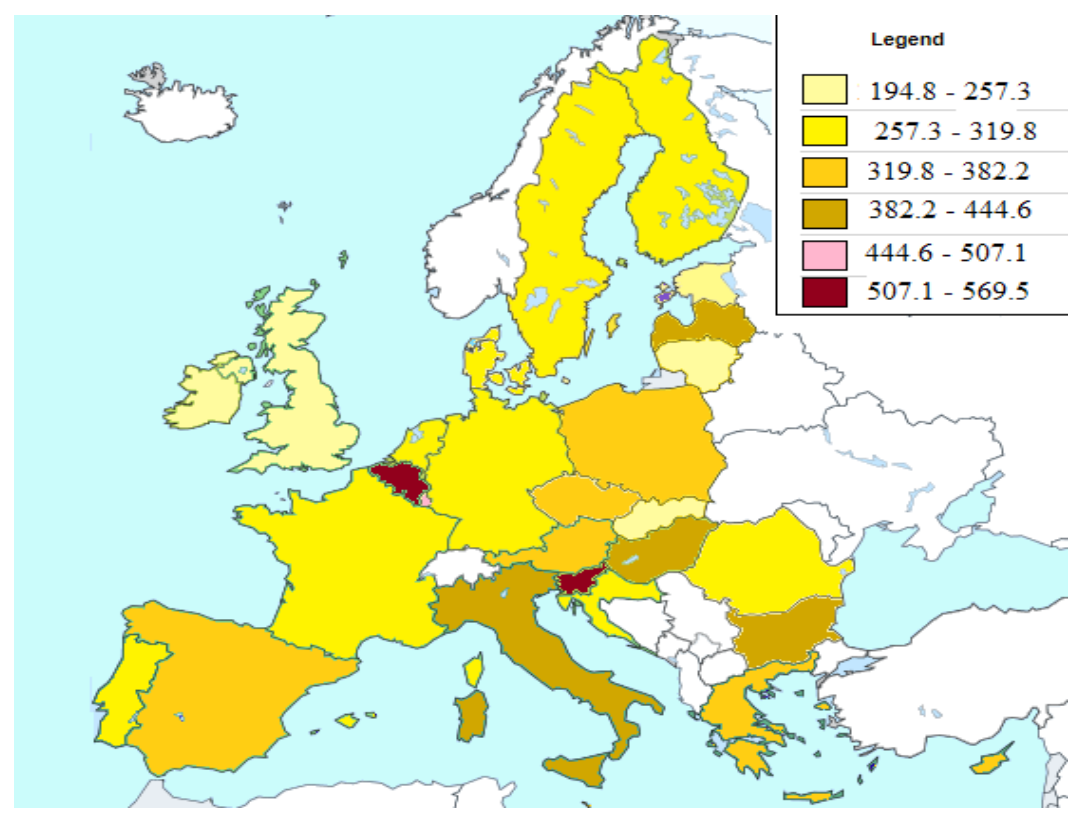

Source: authors`own design based on Mekonnen and Hoekstra (2011a, 2011b)

The concentration curve (Figure 7(c)), traced through the six groups of countries formed, confirms the almost uniform distribution of countries in terms of total gray water footprint of national consumption per capita. By comparing the three graphs of the three types of water footprint, it is noted that the latter has the closest curve to the square's diagonal, highlighting the approximation of the uniform distribution; this tendency is supported by the results of the concentration indicators (Table 2) which are very close to the upper limits of Entropy and Normalized Entropy and the lower limits of Herfindahl, Normalized Herfindahl and Gini Coefficient.

The analysis of the degree of concentration of the total water footprint of national consumption per capita for the 28 EU countries is deepened by grouping them into clusters. Considering the statistical data series, synthesized from 1996-2005, referring to the water footprint of national consumption per capita, on the three types (green, blue and gray), a dendrogram (Figure 10) suggesting several clustering solutions (between 3 and 10 clusters) was constructed. 
Figure 10: Dendrogram using Average Linkage method

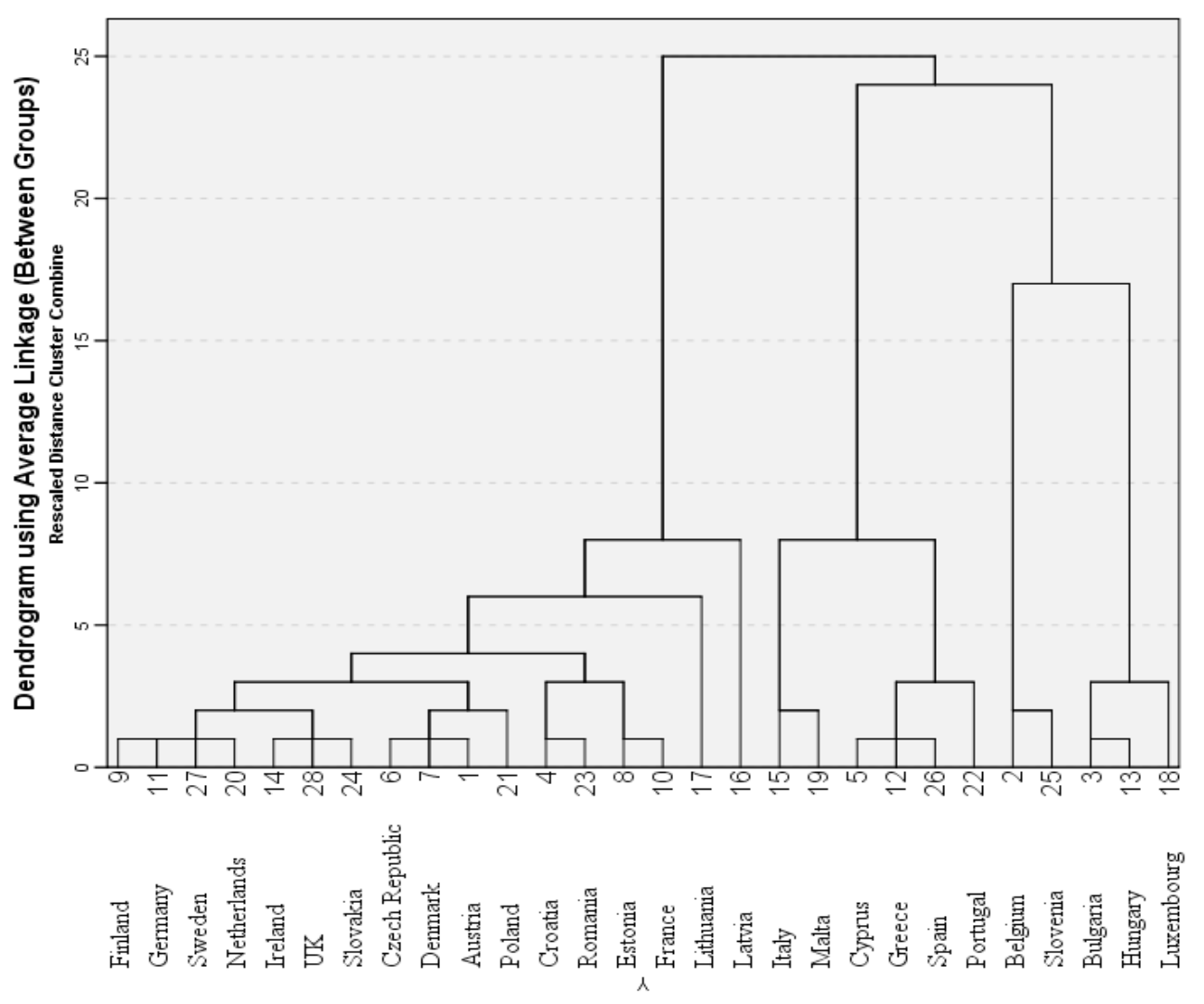

Source: authors`own design based on Mekonnen and Hoekstra (2011a, 2011b)

Subsequently, the methodology determined the number of clusters; the choice is based on both the significant reduction of Total Sum of Squared Error (Peeples, 2011) and better readability of the results. The applied methodology allowed the formation of four significant clusters synthesized by country in Table 3 . These clusters were afterwards used in the analysis of water footprint of national consumption per capita.

Table 3: The structure of clusters determined upon green, blue and gray water footprint of national consumption per capita

\begin{tabular}{|c|l|}
\hline Cluster & \multicolumn{1}{|c|}{ Countries included in clusters } \\
\hline C1 & $\begin{array}{l}\text { Austria, Croatia, Czech Republic, Denmark, Estonia, Finland, France, Germany, Ireland, } \\
\text { Latvia, Lithuania, Netherlands, Poland, Romania, Slovakia, Sweden, UK }\end{array}$ \\
\hline C2 & Belgium, Slovenia \\
\hline C3 & Bulgaria, Hungary, Luxembourg \\
\hline C4 & Cyprus, Greece, Italy, Malta, Portugal, Spain \\
\hline
\end{tabular}

Source: authors' own calculation based on Mekonnen and Hoekstra (2011a, 2011b) 
Testing the statistical validity of the chosen solution (the formation of the four clusters) involves testing the hypothesis that cluster membership of each analyzed variable is not statistically significant (Table 4).

Table 4: The results of testing the hypothesis regarding cluster membership of the green, blue and gray water footprint of national consumption per capita

\begin{tabular}{|c|c|c|c|c|c|}
\hline Variables & $\mathrm{df}_{1}$ & $\mathrm{df}_{2}$ & Fstat & $\mathrm{F}_{0053 \cdot 24}$ & Sig.F \\
\hline Green & 3 & 24 & 44.20 & 3.01 & 0.0000 \\
\hline Blue & 3 & 24 & 35.41 & 3.01 & 0.0000 \\
\hline Gray & 3 & 24 & 23.75 & 3.01 & 0.0000 \\
\hline
\end{tabular}

Source: authors' own calculation based on Mekonnen and Hoekstra (2011a, 2011b)

The results obtained as an outcome of applying relationship (8) (Table 4) show that the analyzed variables are statistically significant from the point of view of cluster membership because the values of $\mathrm{F}$ are higher than the critical value $\mathrm{F}_{0.05,3,24}=3.01$. Fulfilling the conditions of statistical significance for the four clusters allows the analysis of the variables green, blue and gray water footprint of national consumption per capita to be further carried out in relation to the mean values determined and presented in Table 5.

Table 5: The values of clusters' center (means) for the variables green, blue, gray water footprint of national consumption per capita

\begin{tabular}{|c|c|c|c|c|c|}
\hline Variables & & C1 & C2 & C3 & C4 \\
\hline \multirow{4}{*}{ Green } & Mean & 1155.21 & 1280.65 & 1888.90 & 1730.98 \\
\cline { 2 - 6 } & SD & 154.53 & 91.85 & 70.14 & 80.14 \\
\cline { 2 - 6 } & SE & 37.48 & 64.95 & 40.49 & 32.72 \\
\hline \multirow{3}{*}{ Blue } & Mean & 88.56 & 119.70 & 83.93 & 293.18 \\
\cline { 2 - 6 } & SD & 30.46 & 31.82 & 18.94 & 74.15 \\
\cline { 2 - 6 } & SE & 7.39 & 22.50 & 10.93 & 30.27 \\
\hline \multirow{3}{*}{ Gray } & Mean & 292.17 & 549.55 & 425.47 & 344.02 \\
\cline { 2 - 6 } & SD & 50.31 & 28.21 & 38.25 & 33.79 \\
\cline { 2 - 6 } & SE & 12.20 & 19.95 & 22.09 & 13.79 \\
\hline
\end{tabular}

Source: authors' own calculus based on Mekonnen and Hoekstra (2011a, 2011b)

Note: SD - Std. Deviation; SE - Std. Error

The detailed analysis of the results comprised in Table 5 covers all the countries in the clusters, for which the evolution of the three variables green, blue, respectively gray water footprint of national consumption per capita is being studied and compared.

Depending on the mean value at cluster level, corresponding to the three variables taken into analysis, it can be stated that most countries (17 countries) are concentrated in cluster 1 (C1) compared to the other three clusters. The countries in cluster 1 are: Austria, Croatia, Czech Republic, Denmark, Estonia, Finland, France, Germany, Ireland, Latvia, Lithuania, Netherlands, Poland, Romania, Slovakia, Sweden, UK. One 
main characteristic of this cluster is the oscillation of the mean values of the water footprint of national consumption per capita between $915.50 \mathrm{~m}^{3} / \mathrm{yr} / \mathrm{cap}$ (UK) and 1,355 $\mathrm{m}^{3} / \mathrm{yr} /$ cap (Croatia) for green, between $37.70 \mathrm{~m}^{3} / \mathrm{yr} / \mathrm{cap}$ (Croatia) and $156.50 \mathrm{~m}^{3} / \mathrm{yr} / \mathrm{cap}$ (Estonia) for blue and between $194.80 \mathrm{~m}^{3} / \mathrm{yr} /$ cap for Lithuania and $406.20 \mathrm{~m}^{3} / \mathrm{yr} / \mathrm{cap}$ (Latvia) in the case of gray water footprint.

At $95 \%$ level of confidence, the lowest mean consumption of water footprint is recorded for blue $\left(88.56 \mathrm{~m}^{3} / \mathrm{yr} /\right.$ cap per country), whose interval of the mean ranges between $72.90 \mathrm{~m}^{3} / \mathrm{yr} /$ cap per country and $104.32 \mathrm{~m}^{3} / \mathrm{yr} /$ cap per country. As in (Mekonnen and Hoekstra (2011a, 2011b), with a value of $203.61 \mathrm{~m}^{3} / \mathrm{yr} /$ cap per country more than the blue water footprint is the consumption of gray water footprint of national consumption per capita whose interval of the mean ranges between $266.30 \mathrm{~m}^{3} / \mathrm{yr} / \mathrm{cap}$ and $318.04 \mathrm{~m}^{3} /$ $\mathrm{yr} /$ cap per country. The green water footprint of national consumption per capita is the type of water with the highest mean value of consumption with a minimum of $1,075.75$ $\mathrm{m}^{3} / \mathrm{yr}$ /cap per country and a maximum of $1,234.66 \mathrm{~m}^{3} / \mathrm{yr} /$ cap per country as it was measured in Mekonnen and Hoekstra (2011a, 2011b).

Cluster 2 (C2) shows the distribution of water consumption between two countries: Belgium and Slovenia. Corresponding to these two countries, the mean value of green water footprint of national consumption per capita is $25.44 \mathrm{~m}^{3} / \mathrm{yr} /$ cap per country, higher than the one of $\mathrm{C} 1$ and lower compared to the other two clusters (C3, C4). At $95 \%$ confidence, the interval for mean ranges between $455.38 \mathrm{~m}^{3} / \mathrm{yr} /$ cap per country and 2,105.92 $\mathrm{m}^{3} / \mathrm{yr} / \mathrm{cap}$ per country for this particular variable. For Belgium, a reduced consumption of green water footprint of 1,215.7 $\mathrm{m}^{3} / \mathrm{yr} / \mathrm{cap}$ was determined, while Slovenia registers a consumption of $129.9 \mathrm{~m}^{3} / \mathrm{yr} / \mathrm{cap}$ higher than Belgium.

The same situation is also noted in the case of the gray water footprint of national consumption per capita when, compared to Belgium's consumption of $529.6 \mathrm{~m}^{3} / \mathrm{yr} /$ cap, Slovenia has a higher consumption by $39.9 \mathrm{~m}^{3} / \mathrm{yr} /$ cap under the conditions of calculating a mean consumption of $549.55 \mathrm{~m}^{3} / \mathrm{yr} / \mathrm{cap}$, values which are presented in Mekonnen and Hoekstra (2011a, 2011b).

A change between hierarchical positions occupied by the two countries occurs in the case of blue water footprint of national consumption per capita, with a mean consumption of $119.70 \mathrm{~m}^{3} / \mathrm{yr} /$ cap per country. For this type of water, Belgium has a higher consumption by $45.0 \mathrm{~m}^{3} / \mathrm{yr} / \mathrm{cap}$ compared to Slovenia, for which the recorded blue water footprint of national consumption per capita is $97.2 \mathrm{~m}^{3} / \mathrm{yr} /$ cap. Furthermore, cluster 3 (C3) consists of three countries: Bulgaria, Hungary and Luxembourg. The mean value of $1,888.9 \mathrm{~m}^{3} / \mathrm{yr} / \mathrm{cap}$ per country of the green water footprint of national consumption per capita ranges from a minimum of 1,809.20 m³/yr/cap (Bulgaria) and a maximum of 1,941.20 (Luxembourg), Hungary accounting for a value of $1,916.3 \mathrm{~m}^{3} / \mathrm{yr} / \mathrm{cap}$, with a $95 \%$ confidence level, data confirmed in Mekonnen and Hoekstra (2011a, 2011b).

Between Bulgaria and Hungary there is a reversal of the hierarchical positions regarding the consumption of the other two types of water. As in (Mekonnen and Hoekstra (2011a, 2011b), the minimum consumption will be recorded for Hungary instead of Bulgaria 
(65.7 $\mathrm{m}^{3} / \mathrm{yr} /$ cap compared to $82.6 \mathrm{~m}^{3} / \mathrm{yr} /$ cap for blue and $401.8 \mathrm{~m}^{3} / \mathrm{yr} /$ cap compared to $405.0 \mathrm{~m}^{3} / \mathrm{yr} /$ cap for gray). With respect to maximum consumption, the same country, Luxembourg, will have the highest values of $103.5 \mathrm{~m}^{3} / \mathrm{yr} / \mathrm{cap}$ for blue and $469.6 \mathrm{~m}^{3} / \mathrm{yr} /$ cap for gray water footprint, respectively.

The ranking of the six countries (Cyprus, Greece, Italy, Malta, Portugal, and Spain) in cluster $4(\mathrm{C} 4)$, in relation to the mean values of the water footprint of national consumption per capita, changes from one type of water to another. Thus, for the green water footprint of national consumption per capita, the first place regarding the amount of water consumed is occupied by Portugal with 1,854.2 $\mathrm{m}^{3} / \mathrm{yr} / \mathrm{cap}$ and the last by Greece with 1,652 m³/yr/cap (Mekonnen and Hoekstra (2011a, 2011b). Given these limits, fluctuations in water consumption are placed for this cluster and water type around the mean of $1,730.98 \mathrm{~m}^{3} / \mathrm{yr} /$ cap per country. In a confidence interval of $1,646.88 \mathrm{~m}^{3} / \mathrm{yr} /$ cap per country and $1,815.09 \mathrm{~m}^{3} / \mathrm{yr} /$ cap per country ( $95 \%$ confidence), the other four countries are ordered as follows: Spain with 1,802.1 $\mathrm{m}^{3} / \mathrm{yr} / \mathrm{cap}$, Italy with $1720.5 \mathrm{~m}^{3} / \mathrm{yr} / \mathrm{cap}$, Cyprus with $1682.3 \mathrm{~m}^{3} / \mathrm{yr} / \mathrm{cap}$ and Malta with $1674.8 \mathrm{~m}^{3} / \mathrm{yr} / \mathrm{cap}$ as in Mekonnen and Hoekstra (2011a, 2011b).

Blue water footprint of national consumption per capita shows a mean value of consumption of $293.18 \mathrm{~m}^{3} / \mathrm{yr} /$ cap per country, for a $95 \%$ confidence level, in a confidence interval between $215.37 \mathrm{~m}^{3} / \mathrm{yr} /$ cap per country and $371.00 \mathrm{~m}^{3} / \mathrm{yr} /$ cap per country. For this type of water, cluster 4 maintains Portugal first with $363.2 \mathrm{~m}^{3} / \mathrm{yr} / \mathrm{cap}$, followed by Cyprus with $349.3 \mathrm{~m}^{3} / \mathrm{yr} / \mathrm{cap}$, Greece in third place with $326.0 \mathrm{~m}^{3} / \mathrm{yr} / \mathrm{cap}$, fourth place for Spain with $321.2 \mathrm{~m}^{3} / \mathrm{yr} / \mathrm{cap}$, then Malta with $206.7 \mathrm{~m}^{3} / \mathrm{yr} / \mathrm{cap}$, and Italy last with $192.7 \mathrm{~m}^{3} / \mathrm{yr} / \mathrm{cap}$. (Mekonnen and Hoekstra (2011a, 2011b).

Regarding the gray water footprint of national consumption per capita, a mean consumption of $344.02 \mathrm{~m}^{3} / \mathrm{yr} /$ cap per country was recorded for cluster 4 . For this type of water, Portugal takes a minimum consumption of $288.10 \mathrm{~m}^{3} / \mathrm{yr} / \mathrm{cap}$ (Mekonnen and Hoekstra (2011a, 2011b). In the increasing order of consumption, the ranking of the countries of this cluster is: Malta with $334.3 \mathrm{~m}^{3} / \mathrm{yr} / \mathrm{cap}$, Spain with $338.0 \mathrm{~m}^{3} / \mathrm{yr} / \mathrm{cap}$, Cyprus with $353.8 \mathrm{~m}^{3} / \mathrm{yr} / \mathrm{cap}$, Greece with $360.1 \mathrm{~m}^{3} / \mathrm{yr} / \mathrm{cap}$ and Italy with $389.8 \mathrm{~m}^{3} / \mathrm{yr} /$ cap, having the highest consumption of gray water. (Mekonnen and Hoekstra (2011a, 2011b).

Another aspect of the water footprint analysis of national consumption per capita across the 28 EU Member States highlights that the territorial distribution obtained as a result of clustering is significantly justified by the GDP of each country. 
Figure 11: Grouping of countries by total water footprint and GDP per capita

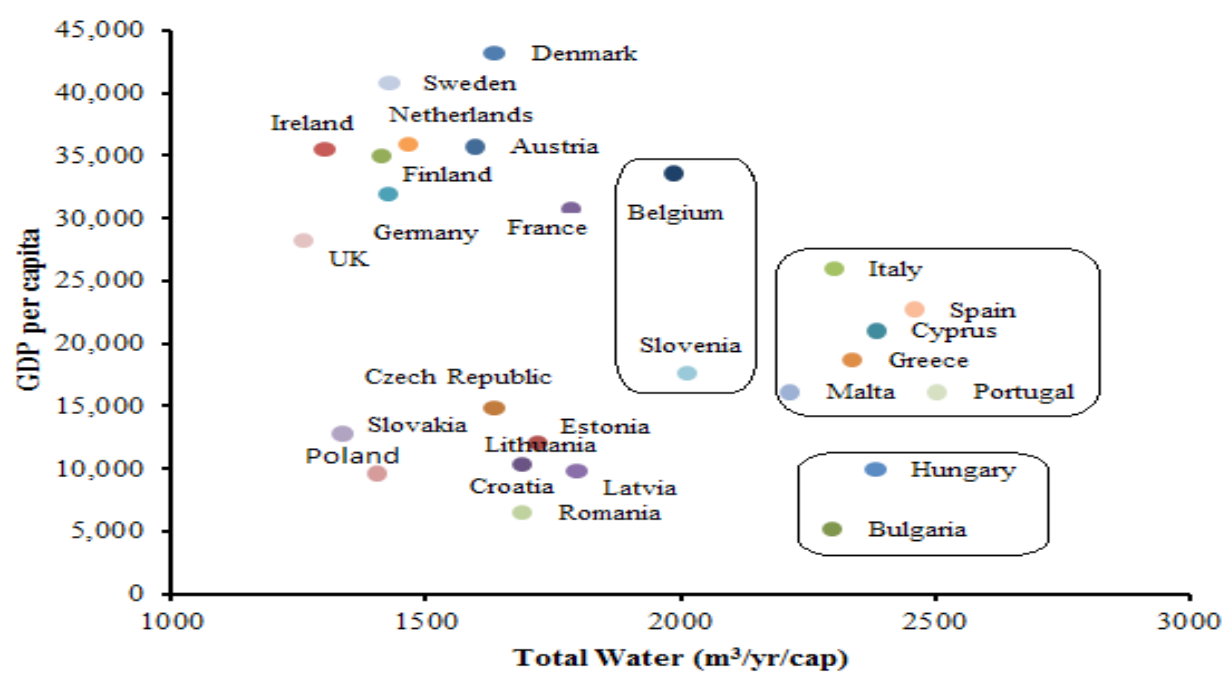

Source: authors`own design based on Mekonnen and Hoekstra (2011a, 2011b)

Taking into account the mean values of the total water footprint of national consumption per capita, a graphical representation (Figure 11) was made in relation to GDP per capita, in order to clearly show their evolution within clusters.

The data included in the analysis determined the concentration of the countries according to the results obtained by the clustering methodology (Table 3) and the graphical representation (Figure 11) into the four clusters presented, which leads to the conclusion that the GDP significantly influences the distribution of the water footprint. The obtained results and the graphical representations reflect the low and moderate concentration of the three types of water footprint of national consumption per country.

\section{Conclusions}

The paper presents certain aspects related to the degree of territorial concentration of water footprint of national consumption across the $28 \mathrm{EU}$ Member States, considering the three known components: green, blue and gray water footprint. The analysis of the territorial concentration was completed by applying the trapezoid method and the concentration indicators: Entropy, Maximum Entropy, Normalized Entropy, Herfindahl, Normalized Herfindahl, Gini Coefficient, and Concentration Coefficient, and graphical representation through the Concentration Curve namely the Lorenz Curve. At the same time, this analysis was supplemented by the application of the clustering method for the water footprint of national consumption, in the context of highlighting the impact of GDP on water consumption.

The results have led to the conclusion that, overall, the total water footprint of national consumption in the $28 \mathrm{EU}$ countries has a very low degree of concentration, therefore, 
tends towards uniformity. With regard to the three types of water footprint, there is a low level of concentration in the case of gray and green water footprint, while the blue water footprint provides a distribution with a moderate degree of concentration.

Taking into account the results, the composition of each type of water footprint and the direct factors mentioned in the introduction that act upon it, clearly explain that the water footprint distribution places the following six countries as water-consuming: Greece, Hungary, Cyprus, Spain, Portugal, and Luxembourg; the lowest water consumption is recorded in the UK, Ireland, Slovakia, Poland, Finland, Germany, Sweden, Netherlands.

The eight countries presented as low water-consuming hold their position also for green water footprint due to climate conditions and excessive consumption of meat and agricultural products. At the opposite pole Hungary, Bulgaria, Spain, Portugal and Luxembourg are situated, which, according to the ranking of the territorial distribution of the green water footprint, register the largest quantities of water consumed.

Four of the six water-consuming countries (Spain, Greece, Cyprus, and Portugal) find themselves in the distribution of blue water footprint. Depending on the way it is formed, the climate and the landscape of each country, the low water footprint consumption is justified and listed for: Croatia, Lithuania, Poland, Latvia, Hungary, Slovakia, Romania, Finland, Czech Republic, Bulgaria and Germany. Belgium and Slovenia are the countries with high gray water footprint consumption, while Lithuania, Slovakia, Estonia, UK, and Ireland occupy the last places in the hierarchy of countries consuming this type of water.

The results of clustering highlight the same aspects of territorial concentration of water types by country, but the four clusters complete the analysis of the mean values obtained and the link with the GDP, stressing the place and role of the water footprint in the EU as a whole, but also in the economy of each country. These results, employing concentration methods, lead to a hierarchy that emphasizes to a certain extent the level of each Member State, proving useful for the national policy adopted by each country. At the same time, as they represent a firm starting point, the perspectives of analyses of the water footprint distribution can be continued both on the three types of water and on the various categories of activities (agriculture, industry, domestic), while considering the internal and external dimensions.

\section{Conflict of interests}

The authors declare no conflict of interest.

\section{References}

1. Eskov, V. M., Eskov, V. V., Vochmina, Y. V., Gorbunov, D. V., and Ilyashenko, L. K. (2017). Shannon entropy in the research on stationary regimes and the evolution of complexity. Moscow University Physics Bulletin, 72(3), 309-317. https://doi. org/10.3103/S0027134917030067 
2. European Commission. (2016). Synthesis Report on the Quality of Drinking Water in the Union examining Member States'reports for the 2011-2013 period, foreseen under Article 13(5) of Directive 98/83/EC. Brussels.

3. Galli, A., Wiedmann, T., Ercin, E., Knoblauch, D., Ewing, B., and Giljum, S. (2012). Integrating Ecological, Carbon and Water footprint into a "Footprint Family" of indicators: Definition and role in tracking human pressure on the planet. Ecological Indicators, 16, 100-112. https://doi.org/10.1016/j.ecolind.2011.06.017

4. Gallopin, G.C., andRijsberman,F.(2000). Threeglobalwaterscenarios. International Journal of Water, 1(1), 16-40. https://doi.org/10.1504/IJW.2000.002055

5. Hoekstra, A. Y., and Chapagain, A. K. (2007). Water footprints of nations: Water use by people as a function of their consumption pattern. In E. Craswell, M. Bonnell, D. Bossio, S. Demuth, and N. Van De Giesen (Eds.), Integrated Assessment of Water Resources and Global Change (pp. 35-48). Dordrecht: Springer Netherlands. https://doi.org/10.1007/978-1-4020-5591-1

6. Hoekstra, A. Y., and Mekonnen, M. M. (2012). The water footprint of humanity. Proceedings of the National Academy of Sciences, 109(9), 3232-3237. https://doi. org/10.1073/pnas.1109936109

7. Kaplowitz, M. D., and Witter, S. G. (2008). Agricultural and residential stakeholder input for watershed management in a mid-Michigan watershed. Landscape and Urban Planning, 84(1), 20-27. https://doi.org/10.1016/j.landurbplan.2007.06.004

8. Keselman, H. J., Othman, A. R., Wilcox, R. R., and Fradette, K. (2004). The New and Improved Two-Sample t Test. Psychological Science, 15(1), 47-51. https://doi. org/10.1111/j.0963-7214.2004.01501008.x

9. Lamastra, L., Suciu, N. A., Novelli, E., and Trevisan, M. (2014). A new approach to assessing the water footprint of wine: An Italian case study. Science of The Total Environment, 490, 748-756. https://doi.org/10.1016/j.scitotenv.2014.05.063

10. Mekonnen, M. M., and Hoekstra, A. Y. (2011a). National water footprint accounts: the green, blue and grey water footprint of production and consumption. Delft., a available at: http:/www.waterfootprint.org/Reports/Report50NationalWaterFootprints-Vol1.pdf; and nd Appendix VIII -IX available at: https:// waterfootprint.org/media/downloads/Report50-Appendix-VIII\&IX.xls

11. Mekonnen, M. M., and Hoekstra, A. Y. (2011b). The green, blue and grey water footprint of crops and derived crop products. Hydrology and Earth System Sciences, 15(5), 1577-1600. https://doi.org/10.5194/hess-15-1577-2011

12. Mooi, E., and Sarstedt, M. (2011). A Concise Guide to Market Research. Berlin, Heidelberg: Springer Berlin Heidelberg. https://doi.org/10.1007/978-3-642-125416

13. Peeples, M. A. (2011). R Script for K-Means Cluster Analysis. Retrieved January 18, 2018, from http://www.mattpeeples.net/kmeans.html 
14. Ridoutt, B. G., and Pfister, S. (2013). A new water footprint calculation method integrating consumptive and degradative water use into a single stand-alone weighted indicator. The International Journal of Life Cycle Assessment, 18(1), 204-207. https://doi.org/10.1007/s11367-012-0458-z

15. Săvoiu, G., Crăciuneanu, V., \& T,aicu, M. (2010). O metodă statistică nouă de analiză a concentrării sau diversificării piețelor. Revista Română de Statistică, (58), 2

16. Sima, V., and Gheorghe, I. G. (2015). Challenges and Opportunities Of The Ecological Footprinting In Romania. Annals of the „Constantin BrâNcuşi” University of TâRgu Jiu, Economy Series, (Special Issue), 108-113.

17. Sonnenberg, A., Chapagain, A., Geiger, M., and August, D. (2009). The Water Footprint of Germany-Where Does the Water Incorporated in our Food Come From? Frankfurt am Main.

18. van Oel, P. R., Mekonnen, M. M., and Hoekstra, A. Y. (2009). The external water footprint of the Netherlands: Geographically-explicit quantification and impact assessment. Ecological Economics, 69(1), 82-92. https://doi.org/10.1016/j. ecolecon.2009.07.014

19. Vanham, D., and Bidoglio, G. (2013). A review on the indicator water footprint for the EU28. Ecological Indicators, 26, 61-75. https://doi.org/10.1016/j. ecolind.2012.10.021

20. Varela-Ortega, C., Rodríguez Casado, R., Ramón Llamas, M., Novo, P., Aldaya, M., and Garrido, A. (2009). Water footprint and virtual water trade in Spain. In Water Policy in Spain (pp. 49-59). Leiden: CRC Press. https://doi. org/10.1201/9780203866023.ch6

21. Wessa, P. (2018). Free Statistics Software, Office for Research Development and Education, version 1.2.1. Retrieved January 15, 2018, from https://www.wessa.net/ stat.wasp

22. Zaiontz, C. (2017). Real Statistics Using Excel. Retrieved October 26, 2017, from http://www.real-statistics.com/

23. Zhao, X., Chen, B., and Yang, Z. F. (2009). National water footprint in an inputoutput framework-A case study of China 2002. Ecological Modelling, 220(2), 245-253. https://doi.org/10.1016/j.ecolmodel.2008.09.016 